\title{
SMART SPECIALISATION DEVELOPMENT OPPORTUNITIES IN THE PIERIGAS REGION (LATVIA)
}

Baiba RIVŽA, Faculty of Economics, Latvia University of Agriculture, Svetes iela 18 Jelgava, LV 3000, Latvia, baiba.rivza@1lu.lv Ligita ĀZENA, Latvia University of Agriculture, Latvia, Svetes iela 18 Jelgava, LV 3000, Latvia, azenaligita@gmail.com (corresponding author)

\begin{abstract}
There are two widely used "smart" concepts, often considered to be synonymous with one another - "smart city" and "smart specialisation". The origin and initial meaning of each concept is different, although there are certain similarities. On the city level, multiple policy initiatives are oriented towards the concept of a "smart city", which originally developed around the ICT infrastructure as a means to connect cities and thus provide opportunity for development. Recently the term "smart" has also found its way in regional policy. Therefore, it is necessary to interpret both concepts in a wider sense not limiting them only to meanings associated with technology. There is an empirical connection between smart specialisation development (in a wider sense) and introduction of smart cities (in a wider sense). But it does not mean that all regions (especially those with low manufacturing development index) should follow a strategy of research and development and/or hi-tech manufacturing.

Smart development is a multi-dimensional concept, consisting of sustainable economic growth and sustainable city or regional development, based on the advantages of sustainable competition. It is also perceived as means to increase overall quality of life. This means that social and environmental capital also plays an important role together with infrastructural and ICT development.
\end{abstract}

Keywords: Economic Developments, Smart Development, Smart Specialisation.

\section{INTRODUCTION}

Smart specialisation relies on an entrepreneurial process of discovery that can reveal domains of economic activity where a country or region excels or has the potential to excel in the future. It empowers entrepreneurs who are able to combine the necessary knowledge about science, technology and engineering with knowledge of market growth and potential in order to identify the most promising activities. In this learning process, entrepreneurial actors have to play the leading role in discovering promising areas of future specialisation, because the needed adaptations to local skills, materials, environmental conditions, and market access conditions are unlikely to be able to draw on codified, publicly shared knowledge, and instead will entail gathering localised information and the formation of social capital assets. One implication for policy makers is that this requires ensuring policy tools to collect the "entrepreneurial knowledge" embedded in the region to transform it into policy priorities. In this context, entrepreneurial actors are not only the people creating new companies but also innovators in established companies, in academia or in the public sector. (Innovationdriven Growth in Regions: The Role of Smart Specialisation, 2013)

Traditionally, the goal of smart specialisation is to concentrate resources for comparatively the most promising fields, for example, existing sectors, and collaborative operations, eco-innovation, high added value markets or specific research areas. The concept of smart specialisation is based on the following characteristics: bottom-up development of research and innovation sectors (Bottom-up investing is an investment approach that focuses on the analysis of individual stocks and deemphasizes the significance of economic cycles and market cycles (Innovation-driven Growth in Regions: The Role of Smart Specialisation (2013) and processes which reveal a suitable regional specialisation. Unlike regions leaders in intensive research, which create new knowledge for general technology (for example, ICT, biotechnology, etc.), and regions - leaders in innovation that is based on the use of new knowledge, the role of local government is pronounced by concentration of social resources in the most promising areas of specialisation and well as collaborations between clusters within region and between neighbouring regions.

The aim of the project was to determine the possibilities of smart specialisation in the Riga planning region. To reach the aim, the following tasks were set: 1) develop smart specialisation evaluation criteria; 2) based on the developed criteria, carry out an analysis of Riga planning districts. Research methods: document analysis, statistical data analysis, SWOT analysis.

Copyright (C) 2017 The Authors. Published by Aleksandras Stulginskis University. This is an open-access article distributed under the terms of the Creative Commons Attribution License (CC-BY 4.0), which permits unrestricted use, distribution, and reproduction in any medium, provided the original author and source are credited. 
"The basis for the concept of smart specialisation is the concept of improving local knowledge and teaching" (McCann un Ortega-Argiles, 2011). This means that the concept includes more than overarching, resource-based, existing and potential specialisation development that is based on technology and ICT development. "Regional smart specialisation policy progress will therefore demand well-planned action and involvement of local participants and institutions (Barca, 2009). Therefore, smart specialisation can be characterised with a goal-oriented collaboration of all involved parties across all levels (Innovation-driven Growth in Regions: The Role of Smart Specialisation, 2013). "It is important to include all questions regarding local non-material capital, including skills, competencies and institutional questions in any regional smart specialisation strategy" (Riga planning regional smart specialisation, 2014).

Thoroughly considered specialisation involves formation and development of a vision by identifying the most competitive advantages, strategic priorities and use of smart policy to increase the knowledge-based potential in any region, be it strong or weak, with access to high technologies or low technologies.

Traditionally, smart specialisation schema is focussed on development of long-term technical infrastructure and knowledge-heavy economy, that is, clever extraction and consumption of energy, highly developed ICTs, knowledgebased green economy, medicine, engineering. This characterised the general principles of smart specialisation, but there is a lack of emphasis on development that is suitable for a particular region and the high importance of collaboration.

Support for smart business environment development aimed to attract both domestic and foreign investors, and to promote new business start-ups and existing business expansion in the municipality, creating new jobs in the population, reduce the drain on the other areas. It is important to determine the areas aid guidelines taking into account the specificity of each territory and opportunities, thus defining the direction of development and the possible specialization.

It is necessary to increase economic activity in areas near the big cities, attracting and using the surrounding areas of resources in support of business, transport and ICT infrastructure to fully exploit and develop the potential of educational institutions and encouraging the mobility of citizens. It would encourage new business and job creation, stimulating the life and work of the great city nearby.

\section{MATERIALS AND METHODS}

Two methods were used to analyse Riga planning region smart specialisation development: an evaluation system developed by Vienna Technical University (smart economy, smart people, smart administration, smart mobility, smart environment and smart living) and the research results of State research programme EKOSOC-LV project 5.2.3. "Processes and opportunities of Latvian regional and rural development within the context of knowledge economy".

During the study, we tested the assumption whether, three of the six aforementioned characteristics can be considered to be the strengths of Latvia: smart people, smart living and smart environment. Furthermore, promoting Latvian and Riga planning region to comply with characteristics of smart administration and smart mobility, could result in a smart and efficient economy that could be considered to be the cornerstone to develop smart specialisation of Riga planning region. (Riga planning regional smart specialization, 2014). The data from the EKOSOC-LV 5.2.3 project confirm a nationwide trend, because development of three regions, was evaluated as smart economy by our experts. During the study, we developed a hierarchy analysis model for each Latvian region, carried out expert interviews, and analysed the acquired data.

\section{RESULTS AND DISCUSSION}

\section{Comparative analysis of the districts of Riga planning region}

Globalization and demographic change, in recent decades occurred in urban and rural areas, the role and prospects of development change. Because people from rural areas have moved to the cities, because there has wider work, education and entertainment options, as well as urban areas offer a much higher quality of life standards. Cities have become very important for a country's economic success in the creation, in the city are those that attract and which focuses growth significant resources that globalization has become very mobile - human resources (people, students, tourists, etc.), companies, investors, research, development of innovation, large-scale events, etc.

To evaluate all opportunities for smart specialisation of Riga planning region, one needs to understand the present situation in the region, its specifics, and projected role in the context of future trends. It is important to carry out evaluation and understand the potential on all levels starting from the whole region, down to individual locations. In the present study, we evaluated the situation at the regional level employing two different methods. One of them includes summarising and comparison of developmental indicators, which explains the present situation via a territorial development index.

Table 1. Pieriga planning region economic profile

\begin{tabular}{|c|c|}
\hline Territory & Local governments $30 \quad$ Republic cities 2 Rīga, Jūrmala \\
\hline & Regional centres 4 Tukums, Ogre, Sigulda, Limbaži \\
\hline Inhabitants & 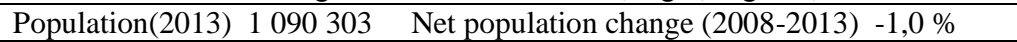 \\
\hline & Population density $105 \mathrm{ppl} / \mathrm{km}^{2} \quad$ in Riga $165 \mathrm{ppl} / \mathrm{km}^{2}$ \\
\hline Economic & IKP (2010) 11690 EUR per capita. Income tax (2012) 554 EUR/pers. \\
\hline & Number of businesses (2011) $77662 \quad$ Average wage (2013) 785 EUR \\
\hline
\end{tabular}

Source: Riga planning region's economic profile, 2014 


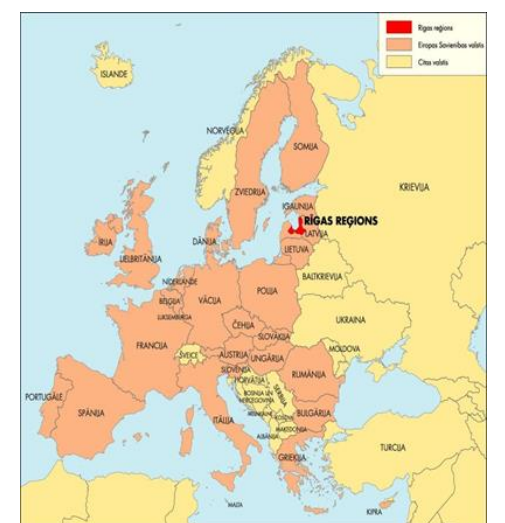

Figure 1. Riga planning region within Europe Source: Riga planning region's economic profile, 2014

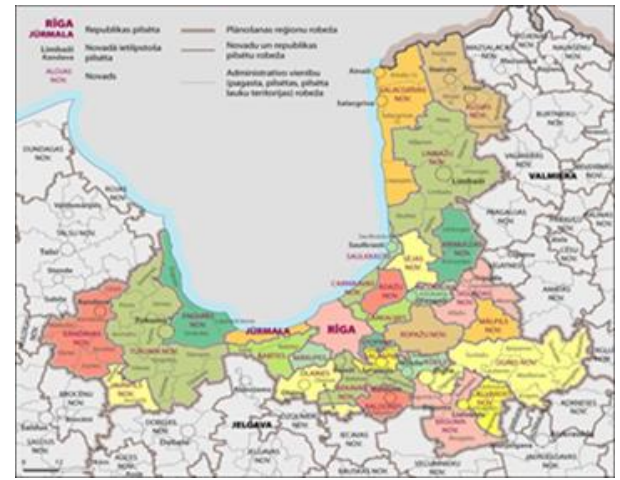

Figure 2. Administrative territories of the Riga planning region Source: Riga planning region's economic profile, 2014

Riga planning region (See Fig. 1,2) is region of the capital city and is presently heavily monocentric. Riga city is the socioeconomic core that develops a wide network of functional ties around it. The suburban areas are becoming home to a society that chooses to work in the Riga city, but live just outside of it - area commonly known as Pieriga (see Table 1). (Riga Planning Region of the current situation description and analysis, 2014). Keeping in mind the aforementioned regional characteristics, we summarised 28 basic indicators of development for 28 regions, which were then used to evaluate smart economy trends ( 8 indicators per region) (data from the EKOSOC-LV 5.2.3 project). To explore the situation, we initially divided the data into 28 regional clusters (excl. Riga and Jurmala cities), based on smart economy indicators. (see Tebles 2 and 3). (Basic development indicators of planning regions, republic cities and regions, VARAM, 2014)

Traditionally, regional government data describing development only include demographic data and basic economic indicators, therefore results are not always objective, and do not characterise potential development. These data clearly show the unequal social and economic situation in the region, emphasise the reasons for social and economic conflict in Riga and Pieriga, clearly describe the monocentric nature of the region and the consequent difficulties regarding the overall development of the region. Following the determination of the middle rank, regions with varied demographic and economic indications can be clearly identified. (Riga planning regional smart specialization, 2014)

Clusters of similar positions:

1. Leader regional governments of Pieriga territories - Ādažu, Baldones, Carnikavas, Engures, Garkalnes, Ikšķiles, Ķekavas, Lielvārdes, Ogres, Olaines, Ropažu, Salaspils, Saulkrasti and Siguldas regions;

2. Direct Pieriga territories - Babīte, Inčukalns, Mārupe and Stopini regions;

3. Central and coastal territories - Aloja, Kandava, Krimulda, Ķegums, Limbaži, Mālpils, Salacgrīva, Sēja and Tukums regions;

4. Remote territories - Jaunpils region.

The 28 regions of the Riga planning region were divided in 4 groups based on cluster analysis. Direct Pieriga territories (Group 3) exhibit the highest indicators, followed by Group 4 (territories close to Pieriga) Group 2 (Central and coastal territories) and Group 1 (Remote territories). Cluster analysis includes the most important indicators - the percentage of population with higher education, number of innovative businesses, innovative business employees, turnover per employee, number of self-employed individuals per 1000 people, the amount of EU funding and support attracted per 1000 inhabitants. (Table 2).

Table 2. Distribution of RPR regional economic profile data clusters

\begin{tabular}{|c|c|c|c|c|}
\hline \multicolumn{4}{|c|}{ Final Cluster Centers } \\
\hline & \multicolumn{4}{c|}{ Cluster } \\
\cline { 2 - 5 } & 1 & 2 & 3 & 4 \\
\hline Number of Cases in each Cluster & 1 & 9 & 30,73 & 26,46 \\
Higher Ed. & 11,90 & 16,14 & 27 & 27 \\
Innovative businesses & 14 & 18 & 5,83 & 9,49 \\
Innov. bus. turnover & 9,95 & 3,45 & 12 & 18 \\
Innov. bus. employees & 9 & 10 & 22030 & 23797 \\
Turnover per employee & 64350 & 10811 & 17 & 20 \\
Self-employed per 1000 inhabitants & 18 & 27 & 3027922,64 & 884332,04 \\
ERAF_ESF_KF, EUR per 1000 inhabitants & 152316,28 & 749208,19 & 280369,36 & 428252,46 \\
ELGF_ELFLF_ZF, EUR per 1000 inhabitants & 7261914,66 & 2017783,86 & 28036 \\
\hline
\end{tabular}

Source: by the author, data from the EKOSOC-LV 5.2.3 project.

Table 3 summarises local governments of the Riga planning region in a ranking based on their basic indicators of development. This clearly draws a picture, where the regions in near proximity of Riga city as well as some leader regional governments exhibit positive demographic indicators, lower unemployment and more local government income per capita 
due to more income tax to be collected. At the same time, other regions lag behind with lower population density, larger share of population outside working age and a significantly smaller number of economically active statistical units in the market sector. Situation reveals a significant factor that is impeding smart development - high degree of centralisation, development of a metro area which lacks its own economic basis - vast suburban areas that use services and infrastructure of the capital city, but do not support the capital city with tax payments, instead funding nearby Pieriga local governments. This situation has to be solved by means of planned and continuous collaboration, creation of new jobs in Pieriga territories, and releasing Riga city from some of the state and governing functions.

\section{Comparative analysis of Riga planning region territorial development}

To evaluate opportunities for development of Riga planning region smart specialisation, it is important to understand the present situation of the region, specifics and the prospective role in the context of future trends and evaluate the situation and potential in the regions.

Riga planning region is region of the capital city and is presently heavily monocentric. Riga city is the socioeconomic core that develops a wide network of functional ties around it. The suburban areas are becoming home to a society that chooses to work in the Riga city, but live just outside of it - area commonly known as Pieriga (see Table 1). (LR Ministry of Economy report on the business environment, 2015).

As data traditionally thought to describe the basic indicators of development are mostly focused on demographics and economy, while not objectively describing development opportunities of local governments and potential for specialisation, the present study focussed on criteria describing smart specialisation.

Table 3. Cluster analysis of the Riga planning region territories by basic indicators of development

\begin{tabular}{|c|c|c|c|}
\hline \multicolumn{4}{|c|}{ Cluster Membership } \\
\hline Case Number & Region & Cluster & Distance \\
\hline 1 & $\overline{\text { Ādaži region }}$ & 4 & 73296,224 \\
\hline 2 & Aloja region & 2 & 1398033,160 \\
\hline 3 & Babīte region & 3 & 162011,057 \\
\hline 4 & Baldone region & 4 & 122521,418 \\
\hline 5 & Carnikava region & 4 & 300479,304 \\
\hline 6 & Engure region & 4 & 716362,142 \\
\hline 7 & Garkalne region & 4 & 859653,855 \\
\hline 8 & Ikšķile region & 4 & 180588,861 \\
\hline 9 & Inčukalns region & 3 & 909183,239 \\
\hline 10 & Jaunpils region & 1 &, 000 \\
\hline 11 & Kandava region & 2 & 597046,835 \\
\hline 12 & Krimulda region & 2 & 712749,367 \\
\hline 13 & Ķegums region & 2 & 726816,884 \\
\hline 14 & Kekava region & 4 & 277754,648 \\
\hline 15 & Lielvārde region & 4 & 626930,260 \\
\hline 16 & Limbaži region & 2 & 371170,342 \\
\hline 17 & Mālpils region & 2 & 653666,764 \\
\hline 18 & Mārupe region & 3 & 119839,012 \\
\hline 19 & Ogre region & 4 & 614839,716 \\
\hline 20 & Olaine region & 4 & 266711,656 \\
\hline 21 & Ropaži region & 4 & 170083,142 \\
\hline 22 & Salacgrīva region & 2 & 316868,256 \\
\hline 23 & Salaspils region & 4 & 599074,562 \\
\hline 24 & Saulkrasti region & 4 & 830892,441 \\
\hline 25 & Sēja region & 2 & 373419,069 \\
\hline 26 & Sigulda region & 4 & 161772,787 \\
\hline 27 & Stopiņi region & 3 & 951763,497 \\
\hline 28 & Tukums region & 2 & 565344,789 \\
\hline
\end{tabular}

Source: by the author, Ministry of Environmental Protection and

Regional Development of the Republic of Latvia, by the author, 2015

Pieriga region SWOT analysis was carried out based on 6 characteristics of smart development as per Vienna Technical University. Due to this, regional SWOT can be evaluated in 6 thematic groups:

1. E- Smart economy - competitiveness;

2. S- Smart people - Social and Human Capital;

3. P-Smart governance - Participation;

4. M- Smart mobility - Transportation and ICT;

5. V-Smart environment - Natural resources;

6. Dz- Smart living - Quality of life.

We summarised available statistical data and the analysis of strengths and weaknesses of Riga planning region. ("Riga planning regional smart specialization") Following the criteria describing smart development, we created a 
schematic map overviewing the present situation regarding strengths, weaknesses, opportunities and threats of smart development (Table 4).

Six SWOT analyses for each local government have created a map of characteristics of each municipality regarding smart development. To reveal comparative advantages for each local government, we developed a schematic map (Table 4), where smart development strengths are coloured with brighter colours for each local government, whereas indicators that do not comply with the smart development framework and are, thus, considered to be weaknesses, are comparatively pale. On the right side of the schematic map, results are laid out within a table, showing the dominating strengths, weaknesses, and threats for smart development. For example, the economic competitiveness of Riga city involves more strengths, therefore it is labelled as an overall strength, whereas environment, power-efficiency, and administration of natural resources as well as governance includes more weaknesses and threats, therefore they are labelled as such. Society and mobility are opportunities for Riga city. Regarding threats, smart living (quality of life) can be regarded as one, because quite often Rigans opt to purchase property outside the city and move to the Pieriga municipalities due to the poor quality of life within Riga city. This is especially very characteristic of young families.

The evaluation of smart development criteria within the RPR reveals some correlations in the region (see Fig. 4). Most municipalities show greater strengths and opportunities in the indicators Smart people (social capital), combined with Smart environment (power efficiency, natural resources), with the combination resulting in Smart living. Smart people often are connected with Smart mobility (transportation and ICT), resulting in a more developed Smart economy (competitiveness). Sometimes a connection between Smart people and Smart administration (participation) can be observed, which also results in an improved Smart economy (competitiveness) (Riga planning regional smart specialization, 2014)

Nevertheless, to promote development that could be labelled as "Smart development" balanced throughout the whole Riga planning region and its municipalities, strengths and opportunities would need to outbalance weaknesses and threats in all indicators. Each local government needs to capitalise on their comparative advantages and promote a productive and sustainable development. Local governments should collaborate and their work ought to provide basic goods and services of a good quality throughout the region.

Table 4. Riga planning region municipality smart development criteria

\begin{tabular}{|c|c|c|c|c|c|c|c|c|}
\hline Region & \multirow{2}{*}{\multicolumn{2}{|c|}{$\begin{array}{l}S \\
V\end{array}$}} & \multicolumn{2}{|c|}{$\mathbf{W}$} & \multicolumn{2}{|c|}{$\mathbf{O}$} & \multicolumn{2}{|c|}{$\mathbf{T}$} \\
\hline $\bar{A}$ daži region & & & $\mathbf{E}$ & $\mathbf{P}$ & M & $\mathrm{DZ}$ & & \\
\hline Aloja region & $\mathrm{S}$ & $\mathbf{P}$ & \multicolumn{2}{|c|}{$\mathbf{V}$} & $\mathbf{M}$ & DZ & & \\
\hline Babīte region & \multicolumn{2}{|c|}{ S } & $\mathbf{P}$ & DZ & M & $\mathbf{V}$ & & \\
\hline Baldone region & $\mathbf{E}$ & $\mathbf{V}$ & \multicolumn{2}{|c|}{ M } & S & $\mathbf{P}$ & \multicolumn{2}{|c|}{ DZ } \\
\hline Carnikava region & \multicolumn{2}{|c|}{$S$} & $\mathbf{P}$ & DZ & \multicolumn{2}{|c|}{$\mathbf{V}$} & \multicolumn{2}{|c|}{$\mathbf{E}$} \\
\hline Engure region & V & DZ & $\mathbf{E}$ & $\mathbf{P}$ & \multicolumn{2}{|c|}{ M } & & \\
\hline Garkalne region & S & M & $\mathrm{DZ}$ & $\mathbf{P}$ & \multicolumn{2}{|c|}{$\mathbf{M}$} & \multicolumn{2}{|c|}{$\mathrm{S}$} \\
\hline Ikšksile region & \multicolumn{2}{|c|}{$\mathbf{P}$} & M & $\mathbf{V}$ & $\mathbf{E}$ & $\mathrm{S}$ & \multicolumn{2}{|c|}{ DZ } \\
\hline Inčukalns region & \multicolumn{2}{|c|}{$\mathrm{DZ}$} & $\mathrm{S}$ & $\mathbf{P}$ & $\mathbf{E}$ & $\mathrm{S}$ & \multirow{2}{*}{\multicolumn{2}{|c|}{$\frac{\mathrm{M}}{\mathrm{S}}$}} \\
\hline Jaunpils region & $\mathbf{V}$ & DZ & $\mathbf{M}$ & $\mathbf{E}$ & \multicolumn{2}{|c|}{$\mathbf{P}$} & & \\
\hline Kandava region & $\mathrm{DZ}$ & $\mathbf{V}$ & $\mathbf{E}$ & $\mathbf{M}$ & \multicolumn{2}{|c|}{$\mathbf{P}$} & \multicolumn{2}{|c|}{$\mathrm{S}$} \\
\hline Krimulda region & $\mathrm{DZ}$ & V & \multicolumn{2}{|c|}{$\mathbf{E}$} & \multirow{2}{*}{\multicolumn{2}{|c|}{$\begin{array}{l}\mathbf{P} \\
\mathbf{E}\end{array}$}} & \multicolumn{2}{|c|}{$\mathbf{S}$} \\
\hline Kegums region & \multicolumn{2}{|c|}{$\mathbf{V}$} & $\mathbf{M}$ & $\mathbf{P}$ & & & $\mathbf{S}$ & DZ \\
\hline Ķekava region & \multicolumn{2}{|c|}{$\mathrm{DZ}$} & V & $\mathbf{M}$ & $\mathbf{E}$ & S & \multicolumn{2}{|c|}{$\mathbf{P}$} \\
\hline Lielvārde region & DZ & $\mathbf{V}$ & $\overline{\mathbf{E}}$ & $\mathbf{M}$ & \multicolumn{2}{|c|}{$\mathbf{P}$} & \multicolumn{2}{|c|}{$\mathrm{S}$} \\
\hline Limbaži region & $\mathrm{DZ}$ & $\mathbf{V}$ & & & & & $\mathbf{P}$ & S \\
\hline Mālpils region & & & $\overline{\mathbf{E}}$ & $\mathbf{M}$ & & & & \\
\hline Mārupe region & S & $\mathbf{E}$ & & & DZ & $\mathbf{P}$ & & \\
\hline Ogre region & & & $\mathbf{P}$ & $\bar{E}$ & M & V & & \\
\hline Olaine region & & & M & V & $\mathrm{S}$ & $\mathbf{M}$ & & \\
\hline Ropaži region & & & $\mathbf{P}$ & $\mathbf{V}$ & S & $\bar{M}$ & & \\
\hline Salacgrīva region & $\mathbf{V}$ & DZ & $\mathbf{E}$ & $\mathbf{P}$ & & & & \\
\hline Salaspils region & & & $\mathbf{P}$ & $\mathrm{DZ}$ & $\mathbf{M}$ & $S$ & & \\
\hline Saulkrasti region & $\mathbf{V}$ & $\overline{D Z}$ & & & & & $\mathbf{P}$ & $\mathbf{M}$ \\
\hline Sēja region & $\mathbf{V}$ & DZ & & & S & M & & \\
\hline Sigulda region & & & $\mathbf{P}$ & $\mathbf{M}$ & S & $\mathbf{E}$ & & \\
\hline Stopini region & $\mathbf{P}$ & $\overline{D Z}$ & & & S & $\mathbf{E}$ & & \\
\hline Tukums region & & & DZ & $\mathbf{M}$ & & & $\mathbf{P}$ & S \\
\hline
\end{tabular}

Source: Riga planning regional smart specialization, 2014.

Signage: E- Economic, Dz- Living, V- Environment, S- Society, P- Governance, M- Mobility.

The main advantages and limitations of smart development in the Riga planning region are the space of functional connections, well-developed transportation infrastructure within the borders of the Riga metro area. The development of Riga metro area borders is largely connected to the availability of transport infrastructure - roads, railways, airports and sea ports. It should be noted, however, in order to develop smart specialisation is an important indicator of the economy, which only a half of the 3 region municipalities, as a second important factor is an intelligent environment, which is 
characterised by a strong 16 region municipalities. While mobility (transportation and ICT) only as one region municipalities forte.

\section{CONCLUSIONS}

It is difficult to understand regional development opportunities and potential specialisation when based only on traditionally gathered data as they are mostly focussed on demographic and economic indicators. When evaluating resources and prerequisites of the Riga planning region, one needs to consider the available infrastructure, and economic, social and partner (businesses, organisations) resources.

The research data shows that the direct vicinity of Pieriga and Direct Riga municipalities characterized by positive demographic indicators, lower unemployment and more local government income per capita due to more income tax to be collected. At the same time, other regions lag behind with lower population density, larger share of population outside working age and a significantly smaller number of economically active statistical units in the market sector. Evaluation of RPR municipalities revealed that the main criterion characterising smart specialisation development is Smart economy (competitiveness), which is the most pronounced in Riga and Pieriga municipalities as well as regional cities of Sigulda and Tukums.

\section{ACKNOWLEDGEMENT}

Research supported from National Research programme EKOSOC-LV and Riga Planning Administration.

\section{REFERENCES}

1. ESPON Study,EDORA - European Development Opportunities for Rural Areas. 2013. Available at: http://www.espon.eu/main/Menu_Projects/Menu_AppliedResearch/edora.html (Accessed on: 18/01/2017).

2. Innovation-driven Growth in Regions: The Role of Smart Specialisation (2013). OECD. Available at: http://www.oecd.org/sti/inno/smart-specialisation.pdf (Accessed on: 13/01/2017).

3. LR Ministry of Economy report on the business environment. 2015 . Available at: https://www.em.gov.lv/lv/nozares_politika/nacionala_industriala_politika/uznemejdarbibas_vide (Accessed on: 22/01/2017).

4. National research programs 5.2. " Economic transformation, smart growth, governance and the legal framework of the state and society for sustainable development - a new approach to a sustainable knowledge society (EKOSOC-LV) data. Available at: http://www.lza.lv/index.php?option=com_content\&task=blogcategory\&id=249\&Itemid=443 (Accessed on: 13/01/2017).

5. National Research Programme 5.2.3. Project "Latvian rural and regional development processes and opportunities of the knowledge economy in the of" data. Available http://www.lza.lv/index.php?option=com_content\&task=blogcategory\&id=249\&Itemid=443, (Accessed on: 13/01/2017).

6. Planning regions, city and county development fundamentals (VARAM, 2014), http://www.vraa.gov.lv/lv/petnieciba/statistika/develop/ (Accessed on: 10/01/2017).

7. Riga planning region's economic profile. 2014..

8. Riga Planning Region of the current situation description and analysis. 2014.

9. The research "Riga planning regional smart specialization". 2014. 